\title{
育苗中の移植が蒔の花芽分化並花芽の 發育に及ぼす影響に就て
}

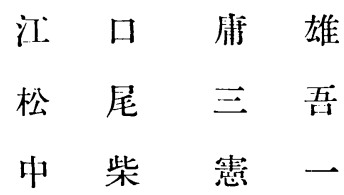

(千葉敫等園攀學校)

\section{I 緒 言}

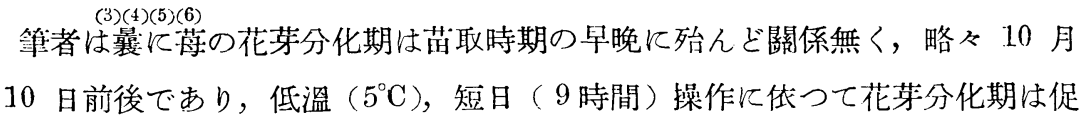
進され，土壤の乾濕は何等影響を及代さす，寧ろ濕潤區に於て花牙分化期の促 進される傾向ある事を述へ，茄子・トマトに在つては育苗中の移植操作は花芽 分化期を後らし，引いては開花結實期を後らす事に就て述べる處があつた。

最近苏の促成栽培日を逐ふて盛んとなり，栽培上に新をな問題を提供して居 るが，特に育桨中に行はれる移植の如き其の一つであつて，從來地方に依つて 1 包乃至 3 包の移植を行ふ處あり，移植の意義に就いても解釋がマチマチであ る。且又, 促成並に一般露地䓅の定植時期に當る 10 月 10 日前後は, 時恰 薄の花芽分化期に當り，此の時期に行はれる定植一一强度の斷根——が果して 花芽の發奇に如何なる影響を及ばすかを知る事は旰要な事と考へ，昭和 11 12 年に亘つて本實驗を行つたものである。

\section{II 材料 及方法}

昭和 11 年には東京地方で最も一般的に栽培されて居る “大島種”(露地荫) を撰び 6 月 29 日に約 250 株の苗を任立て, 次の期日に冬々の移植區を作り,各

\begin{tabular}{|c|c|c|c|c|}
\hline 別 & 移 & 植 & & 日 \\
\hline 標淮 (無移植區) & 育 苗 & 中 無 & 移 & 植 \\
\hline 1 洍移植區 & 一 & 8 月17日 & & - \\
\hline 2 尼移植區 & 7 月17日 & - & & 月 7 日 \\
\hline 3 回移植澏 & 7 月17日 & 8 月 17 日 & & 月 7 日 \\
\hline
\end{tabular}
區共 9 月 20 日より 11 月 20 日 まで5日〜10日每汇3株〜 5 株 の材料を取つて實驗に供した。 昭和 12 年には促成用別種 “福犽種”に就て 6 月 16 日と 
6 月 28 日の 2 包に約 750 株の萌を什立て〉夫规夫れ次の區を設けた。

(6月16日苗取湂)

\begin{tabular}{|c|c|c|c|}
\hline 區 & 移 & 植 & 日 \\
\hline 標準(無移植澏) & 育 荫 & 中 無 & 移 植 \\
\hline 1 问移植澏 & -1 & 8 月 8 日 & \\
\hline 2 可移植區 & 7 月气0日 & - & 8 月 26 日 \\
\hline 3 问移植區 & 7 月14日 & 8 月 8 日 & 9 月 5 日 \\
\hline
\end{tabular}

(6月 28 口苗取躁)

\begin{tabular}{|c|c|c|c|}
\hline 蛊 & 移 & 植 & 日 \\
\hline 標準(無移植谔) & 育 苗 & 中 無 & 移 植 \\
\hline 1 问移植熰 & - & 8 月21口 & 一 \\
\hline 2 问移植嵒 & 8 月 2 日 & - & 9 月 5 日 \\
\hline 3 间移植湢 & 7 月 24 日 & 8 月 21 日 & 9 月 7 日 \\
\hline
\end{tabular}

各區其 9 月 10 日より 11 月 10 日迄 5 日〜 10日每に 4 株〜 5 株の材料を取つて實驗に供し 本年度に於ては無移植區を更に

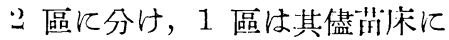
殘し，他の區は一度花芽分化期 に當る 10 月 3 日に掘り取つて 圑場に定植し，花芽分化當時况 行はれる定植一一强度の斷根一 一が花芽の發育飞如何なる影響 を及庄すかを調べる事にした。

賽驗方法㹥算者が今日迄行つ て來た他の埸合と同樣，村料を一應 $70 \%$ のアルコール中に保存して適宜實驗 に供した。育苗中の管理はー一般法に準じて行ひ，嘼は兩年其略ら顺調な發育を して居た。

\section{III 實 驗 結 果}

1. 花芽分化期に及将す影響

(a) 炤和 11 年 (大島種)

各區に於ける分化推移を表示すれば第 1 表に示す通りである。

第 1 表 移植泡數と花芽分化期との關係 （昭和 11 年，大島）

\begin{tabular}{|c|c|c|c|}
\hline 區別 材料探取日 & 10 月 5 日 & 10月10日 & 10 月 16 日 \\
\hline 標準(無移植㸃) & $x$ & $\triangle$ & 0 \\
\hline 1 回移植洫 & $x$ & 0 & 0 \\
\hline 2 四移植澏 & $x$ & $\bigcirc$ & O \\
\hline 3 他移植區 & $x$ & $\mathrm{O}$ & 0 \\
\hline
\end{tabular}

$\times \cdots$ 未分化 $\Delta \cdot \cdots$ 分化初期 $\bigcirc \cdots$ 分化期
10 月5日の材料では各區共 て末分化であつたが，10月 10 日の材料では, 無移植區は 3 株 其分化初期であり，1 包移植區 は 5 秼中 1 株は花芽分化して 4 株牥分化初期であり，2回移植 區は 5 株中 2 株分化して 3 株は

分化初期，3 包移植區は 5 株中 4 株分化して 1 株分化初期の物があつた。郎,

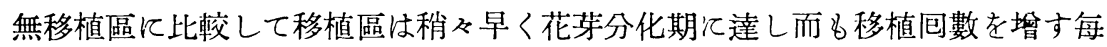
に花芽分化を促進する傾向が見えて居る。 
（b）昭和 12 年 (1) (福犲種，6月 16 日草)

各區に於ける分化推移を表示すれば第 2 表に示す通りである。

第 2 表 花芽分化期比較 (1937.6.16 苗取區)

\begin{tabular}{|c|c|c|c|c|c|c|c|c|c|c|c|c|}
\hline 材料探月日 & & 9 月 & 20 & & & 月 & 30 & & & 10 月 & 11 & \\
\hline 進度、區別 & 無移 & $\begin{array}{l}1 \text { 问 } \\
\text { 移植 }\end{array}$ & $\begin{array}{l}2 \text { 回 } \\
\text { 移植 }\end{array}$ & \begin{tabular}{|l|} 
3间 \\
移植
\end{tabular} & $\begin{array}{l}\text { 無移 } \\
\text { 植 }\end{array}$ & $\begin{array}{l}1 \text { 阳 } \\
\text { 移植 } \\
\end{array}$ & $\begin{array}{l}2 \text { 问 } \\
\text { 移植 }\end{array}$ & \begin{tabular}{|c|}
3 [䜣 \\
移植 \\
\end{tabular} & \begin{tabular}{|l} 
無移 \\
植 \\
\end{tabular} & \begin{tabular}{|c|}
1 间 \\
移植
\end{tabular} & $\begin{array}{l}2 \text { 间 } \\
\text { 移植 }\end{array}$ & $\begin{array}{l}3 \mid \mathrm{e}] \\
\text { 移植 }\end{array}$ \\
\hline 供 試 株 數 & 4 & 5 & 5 & 4 & 4 & 5 & 5 & 5 & 5 & 4 & 4 & 5 \\
\hline 未 分 化 & 4 & 5 & 5 & 2 & 4 & 5 & 2 & & 1 & & & \\
\hline 分 化 初 期 & & & & 2 & & & & & & & & \\
\hline 分 化 期 & & & & & & & & & & & & \\
\hline 分化期經過株 & & & & & & & 3 & 5 & 4 & 4 & 4 & 5 \\
\hline
\end{tabular}

以上に依れば 9 月 20 日の材料で 3 包移植區は 4 株中 2 株は分化初期に達し て最も進み，9月 30 日の材料で，2 包移植區は 5 株中 3 株花芽分化し，3 司 移植區は 5 株共花芽分化期に達して最8僬み，10月 11 日には各區共に花芽分 化に達して居るが無移植區は最も後れて居る。

(c) 昭和 12 年 (2) (福犲種，6 月 28 日㬳)

齐區に於ける分化推移は第 3 表に示す通りである。

第 3 表花芽分化期比較 (1937.6.16 苗取澏)

\begin{tabular}{|c|c|c|c|c|c|c|c|c|c|c|c|c|}
\hline 材料採月日 & \multicolumn{4}{|c|}{9 月 20 日 } & \multicolumn{4}{|c|}{9 月 25 日 } & \multicolumn{4}{|c|}{10 月 5 日 } \\
\hline 度 澏別 & $\begin{array}{l}\text { 橆移 } \\
\text { 植 }\end{array}$ & $\begin{array}{l}1[\mathrm{e}] \\
\text { 移植 }\end{array}$ & $\begin{array}{l}2 \text { 问 } \\
\text { 移植 }\end{array}$ & \begin{tabular}{|l}
3 他 \\
移植
\end{tabular} & 無移 & $\begin{array}{c}1100 \\
\text { 移植 } \\
\end{array}$ & $\begin{array}{l}2 \text { 间 } \\
\text { 移植 } \\
\end{array}$ & $\begin{array}{c}3 \text { [移植 } \\
\text { 和 }\end{array}$ & $\begin{array}{l}\text { 無移 } \\
\text { 植 }\end{array}$ & $\begin{array}{l}1 \text { 狍 } \\
\text { 移植 }\end{array}$ & $\begin{array}{c}2[0] \\
\text { 移植 }\end{array}$ & $\begin{array}{l}3|\overline{\mathrm{U}}| \\
\text { 移植 }\end{array}$ \\
\hline 供 試 株 數 & 5 & 5 & 5 & 5 & 5 & 5 & 5 & 5 & 5 & 5 & 5 & \\
\hline 未 分 化 & 5 & 5 & 5 & 4 & 5 & 5 & 2 & 2 & 3 & 1 & 1 & 1 \\
\hline 分 化 初 期 & & & & 1 & & & 1 & & & 1 & & \\
\hline 分 化 期 & & & & & & & 2 & 2 & 2 & 3 & 3 & 1 \\
\hline 分化期經過株 & & & & & & & & 1 & & & 1 & 1 \\
\hline
\end{tabular}

以上に依れば 9 月 20 日の材料で 3 包移植區は 5 株中 1 株分化初期に達する ものがあつて最も進み，9月 25 日の材料で 2 包移植區は 5 株中 2 株，3 包移 植區は 5 株中 3 株花芽分化期に達するものあり，10月 5 日の材料で無移植區 は 5 株中 2 株， 1 包移植區は 5 株中 3 株，2 包移植區は 5 株中 4 株 3 包移 植區は 4 株中 2 株，花芽分化期飞達するものがあつて，無移植區の花芽分化最 女後れ，移植可數を增す每江花芽分化の促進される傾向を明示して居る。 


\section{(d) 要 約}

以上 2 ケ年，3 包に亘つて得を結果から見れば，大島，福犽種共に同一傾向 を示し，籍者が暴に得た茄子・トマトの場合と反對に，無移植區の花芽分化期最 多後れ，移植司數を增す每に花芽分化期が促進されて居る。

\section{2. 花芽の發育に及卧す影響}

(a) 昭和 11 年 (大島種)

各移植區に於ける花芽の發有推移を比較すれば第 4 表, 第 1 圖, 第 2 圖に示 す通りである。

第 4 裴 移植何數と花芽發育との關係（大島，1936）

\begin{tabular}{|c|c|c|c|c|c|c|c|c|c|}
\hline 月 & 日 & 別 & 分化初期 & 分化期 & 楞片初生 & 花瓣初生 & 雄鉴初生 & $\begin{array}{l}\text { 䒺雌茬 } \\
\text { 初 生 }\end{array}$ & $\begin{array}{l}\text { 花 茅 } \\
\text { 合計數 }\end{array}$ \\
\hline \multirow[t]{4}{*}{$10^{\text {月 }}$} & \multirow[t]{4}{*}{10} & 無 移 植 監 & 1.0 & - & - & 一 & - & -- & 1.0 \\
\hline & & 1 包移植區 & 0.8 & 0.4 & -- & - & - & -- & 1.2 \\
\hline & & 2 问移植湂 & 0.6 & 0.8 & 一 & 一 & - & - & 1.4 \\
\hline & & 3 [和移植區 & 0.2 & 1.6 & - & - & - & $\cdots$ & 18 \\
\hline & 16 & 無 移 植 澏 & - & 2.3 & 0.3 & 一 & - & - & 2.7 \\
\hline & & 1 可移植區 & - & 2.7 & 1.0 & 0.3 & - & - & 4.0 \\
\hline & & 2 间移植區 & - & 3.7 & 0.3 & 1.0 & -- & - & 5.0 \\
\hline & & 3 闰移植兴 & 0.3 & 4.7 & 0.7 & 0.7 & 一 & - & 6.3 \\
\hline & 無移植 噪 & - & 4.0 & 0.7 & 0.7 & - & - & 5.3 \\
\hline & & 1 间移植澏 & - & 5.0 & 1.0 & 1.0 & - & -- & 7.0 \\
\hline & & 2 问移植㽞 & - & 4.0 & 1.0 & 0.7 & - & - & 5.7 \\
\hline & & 3 昰移植澏 & - & 5.3 & 1.0 & 1.0 & 0.7 & - & 8.0 \\
\hline \multirow{4}{*}{\multicolumn{2}{|c|}{30}} & 無 移 植 浯 & 1.5 & 4.0 & 2.0 & 1.5 & 1.5 & - & 10.5 \\
\hline & & 1 四移植澏 & 2.8 & 5.5 & 2.8 & 2.8 & 1.5 & - & 15.3 \\
\hline & & 2 问移植湿 & 2.4 & 6.8 & 2.4 & 2.2 & 2.6 & - & 17.0 \\
\hline & & 3 回移植菭 & 1.0 & 58 & 3.4 & 1.4 & 2.8 & 0.2 & 14.6 \\
\hline \multirow[t]{8}{*}{11} & \multirow[t]{4}{*}{10} & 無 移 植 區 & 1.5 & 9.0 & 3.5 & 2.5 & 4.0 & 1.0 & 21.5 \\
\hline & & 1 包移植灌 & 1.0 & 6.2 & 4.6 & 3.0 & 5.2 & 1.4 & 21.6 \\
\hline & & 2 包移植湂 & 0.6 & 7.8 & 2.2 & 2.4 & 4.6 & 1.8 & 19.4 \\
\hline & & 3 问移植區 & 0.2 & 6.8 & 3.2 & 1.6 & 4.0 & 2.4 & 18.2 \\
\hline & \multirow[t]{4}{*}{20} & 無 移 植 凅 & - & 3.0 & 1.3 & 0.8 & 8.0 & 6.0 & 19.0 \\
\hline & & 1 可移植澏 & - & 5.8 & 2.0 & 1.5 & 7.8 & 4.0 & 21.0 \\
\hline & & 2 问移植签 & -- & 4.5 & 2.8 & 1.0 & 6.0 & 4.0 & 18.3 \\
\hline & & 3 问移植澏 & - & 5.5 & 1.8 & 1.3 & 6.3 & 2.8 & 19.5 \\
\hline
\end{tabular}

詰：花芽分化數を供試株數にて本均して示す 


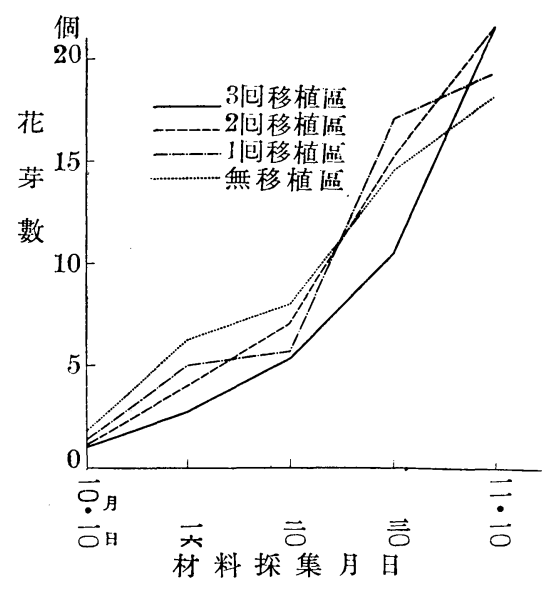

第 1 圖 花芽數比較 薄 (1936) （大島種）

10月1日

10月 5 日

10月 16 日

10月20日

無移植

虽
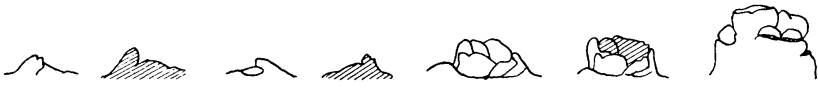

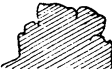

1 四移

植品
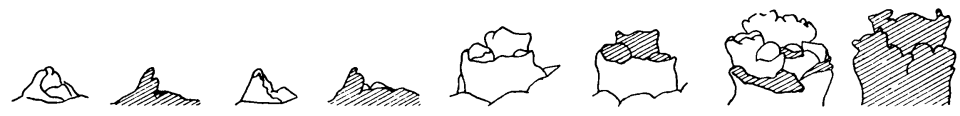

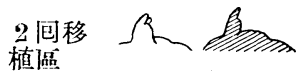
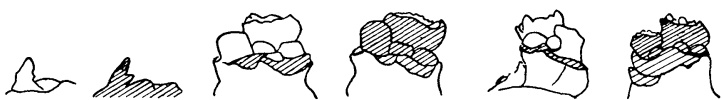

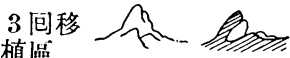
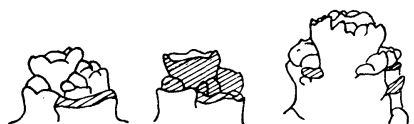

植監
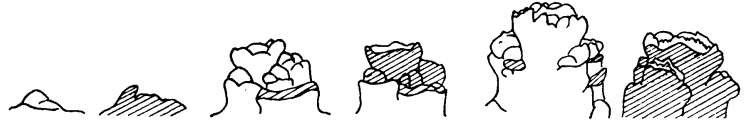

第 2 圖 育苗中の移植可數が薄の花芽分化・發育に及ぼす影暜（1936）(大島種）

薸：斜線を施したのは大れの斷面を示す。

第 5 表 苗取區花器形成比較 (1937.6.16)

\begin{tabular}{|c|c|c|c|c|c|c|}
\hline $\begin{array}{l}\text { 材料探月日 } \\
\text { 湂 別 }\end{array}$ & 9 月 10 日 & 9 月 20 日 & 9 月 30 日 & 10月11日 & 10 月 20 日 & 10月30日 \\
\hline 無 移 植 偘 & 未分化 & 未分化 & 未分化 & 蓦片形成 & 雌篮初生 & 花粉形成 \\
\hline 1 包移植湂 & 未分化 & 未分化 & 未分化 & 花瓣初生 & 䧳熦形戌 & 花粉形成 \\
\hline 2 可移植澏 & 未分化 & 未分化 & 雄蕋初生 & 雄:蓝形成 & 噶 形 成 & 花粉形成 \\
\hline 3 间移植區 & 未分化 & 分化初期 & 雄鉴初生 & 䧳蓝形成 & 䧳䒚形成 & 花粉形成 \\
\hline
\end{tabular}

註：最も進みし株の進度を示す

以上に依れば，花器形成の推移も花芽分化期に略 3 同樣に，無移植區最も後 
れ，移植包數を燴す每に花器形成最も進み，10月30日迄の材料では花芽分化 數も最も多く，1月10日，20日の材料では，各區基花芽分化數略々同じ樣で ある。

（b）昭和 12 年 (1) (福炣種 6 月 16 日苗)

各移植區に於ける花芽の發育推移を比較すれば第 5 表，第 6 表，第 3 圖， 第 4 圖，第 5 圖に示す通りである。

第 6 表 花芽發育進度表（1937.6.16 苗取區）

\begin{tabular}{|c|c|c|c|c|c|c|c|c|c|c|c|c|c|c|c|}
\hline $\begin{array}{l}\text { 材料探 } \\
\text { 月日 }\end{array}$ & 進 & $\begin{array}{l}\text { 供 } \\
\text { 試 } \\
\text { 株 } \\
\text { 數 }\end{array}$ & $\begin{array}{l}\text { 末 } \\
\text { 分 } \\
\text { 化 }\end{array}$ & $\begin{array}{l}\text { 分 } \\
\text { 化 } \\
\text { 初 } \\
\text { 期 }\end{array}$ & $\begin{array}{l}\text { 分 } \\
\text { 化 } \\
\text { 期 }\end{array}$ & $\begin{array}{l}\text { 䓪 } \\
\text { 初 } \\
\text { 生 }\end{array}$ & $\begin{array}{l}\text { 䓪 } \\
\text { 形 } \\
\text { 形 }\end{array}$ & $\begin{array}{l}\text { 花 } \\
\text { 看 } \\
\text { 初 } \\
\text { 生 }\end{array}$ & $\begin{array}{l}\text { 花 } \\
\text { 敨 } \\
\text { 形 } \\
\text { 戊 }\end{array}$ & $\begin{array}{l}\text { 雄 } \\
\text { 蕋 } \\
\text { 初 } \\
\text { 生 }\end{array}$ & $\begin{array}{l}\text { 雄 } \\
\text { 莊 } \\
\text { 形 } \\
\text { 戊 }\end{array}$ & $\begin{array}{l}\text { 雌 } \\
\text { 竹 } \\
\text { 初 } \\
\text { 生 }\end{array}$ & $\begin{array}{l}\text { 雌 } \\
\text { 潅 } \\
\text { 形 } \\
\text { 成 }\end{array}$ & $\begin{array}{l}\text { 葯 } \\
\text { 形 } \\
\text { 成 }\end{array}$ & $\begin{array}{l}\text { 花 } \\
\text { 粉 } \\
\text { 形 } \\
\text { 戊 }\end{array}$ \\
\hline $\begin{array}{cc}\text { 月 } & \text { H } \\
9 & 10\end{array}$ & 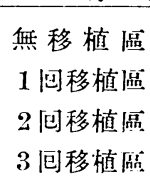 & $\begin{array}{l:l}4 & \\
4 & \\
5 & \\
4 & \end{array}$ & $\begin{array}{l}4 \\
4 \\
5 \\
4\end{array}$ & & & & & & & & & & & & \\
\hline 20 & $\begin{array}{c}\text { 無移植沾 } \\
1 \text { 包移植凅 } \\
2 \text { 回移植湂 } \\
3 \text { 包移植區 }\end{array}$ & $\begin{array}{l}4 \\
5 \\
5 \\
4\end{array}$ & $\begin{array}{l}4 \\
5 \\
5 \\
2\end{array}$ & 2 & & & & & & & & & & & \\
\hline 30 & 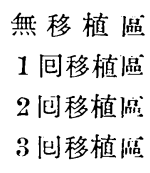 & $\begin{array}{l}4 \\
5 \\
5 \\
5\end{array}$ & $\begin{array}{l}4 \\
5 \\
2\end{array}$ & & & & $\begin{array}{l}1 \\
2\end{array}$ & $\begin{array}{l}1 \\
1\end{array}$ & & $\begin{array}{l}1 \\
2\end{array}$ & & & & & \\
\hline $10 \quad 11$ & 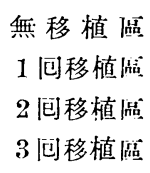 & \begin{tabular}{l|}
5 \\
4 \\
5 \\
5
\end{tabular} & 1 & & 1 & $\begin{array}{l}2 \\
1\end{array}$ & $\begin{array}{l}2 \\
1 \\
1\end{array}$ & 2 & & & 2 & 4 & 1 & & \\
\hline 20 & 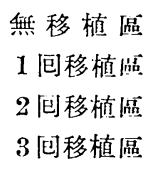 & $\begin{array}{l}4 \\
5 \\
5 \\
5\end{array}$ & & & & 1 & & & & 1 & $\begin{array}{l}1 \\
4 \\
1 \\
1\end{array}$ & $\begin{array}{l}1 \\
2 \\
1\end{array}$ & $\begin{array}{l}1 \\
2\end{array}$ & 2 & \\
\hline 30 & 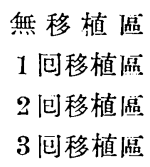 & \begin{tabular}{l|}
5 \\
5 \\
4 \\
5
\end{tabular} & & & & & & & & 1 & $\begin{array}{l}2 \\
2 \\
2\end{array}$ & $\begin{array}{l}2 \\
2 \\
1\end{array}$ & 2 & & $\begin{array}{l}1 \\
1 \\
1 \\
2\end{array}$ \\
\hline
\end{tabular}




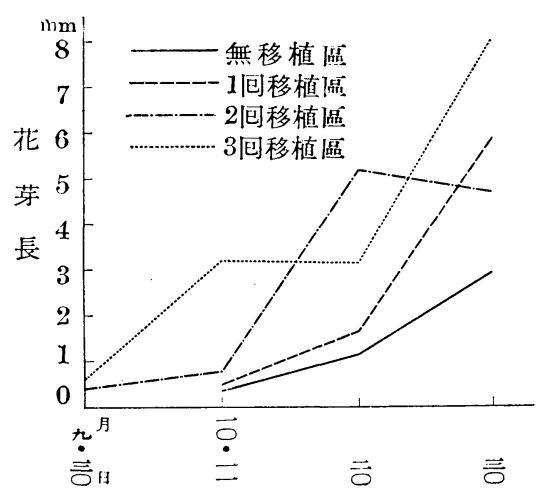

材料探集月日

第 3 圖 花芽比較(1937.6.16苗取監)

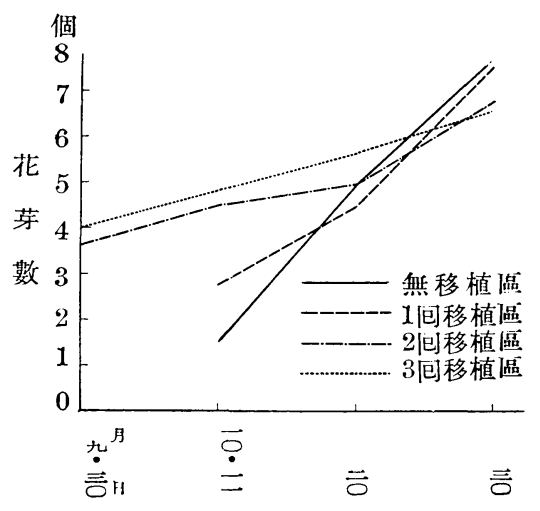

材料探集月日

第 4 圖 花芽數比較( 937.6 .16 苗取區) 9 月20日 9 月 30 日 10 月11日 10 月 20 日

標 準 (無移植浊)

1 问移植浊

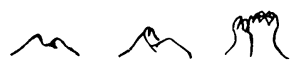
D M

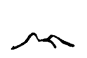

2 问移植監
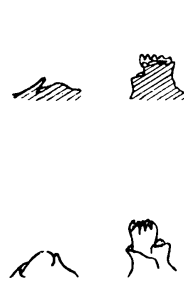

3 包移植温

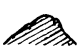

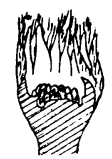
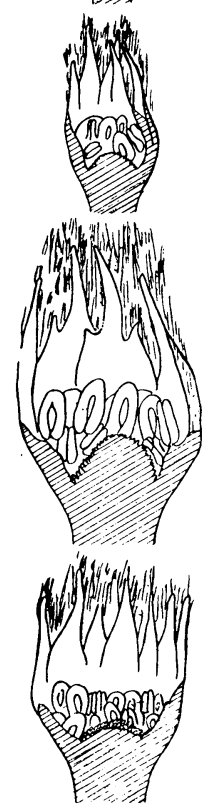

以上に依れば 花器形成の進度 並花芽の發育は 無移植區最8後 れ，移植荓數を 增す每に促進さ れ，花芽の分化 數は 10 月 20 日頃までの材料 で 3 可移植區最 女多いが 10 月 30 日の材料で は無移植區の花 芽分化數次第に 增加して居る。

第 5 圖 移植包數が莓の花芽發育に及ぼす影響 (1937.6.16 苗取區) (福狗種) 
(c) 昭和 12 年 (2) (福犽種 6 月 28 日苗)

各移植區に於ける花芽の發育推移を比較すれば第 7 表，第 8 表，第 6 圖，第 7 圖，第 8 圖に示す通りである。

第 7 表 花器形成比較 (1937.6.28 苗取剾)

\begin{tabular}{|c|c|c|c|c|c|c|c|c|c|c|}
\hline 材料探月日 & $\begin{array}{l}\text { 月 } \mathrm{H} \\
9 .\end{array}$ & .20 & .25 & .30 & 10. 5 & .11 & .15 & .20 & .30 & 11. 10 \\
\hline 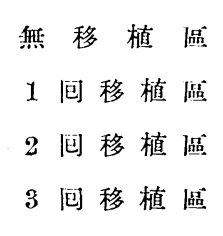 & $\begin{array}{l}\text { 未分化 } \\
\text { 未分化 }\end{array}$ & $\begin{array}{l}\text { 未分化 } \\
\text { 分化初 } \\
\text { 期 }\end{array}$ & $\begin{array}{l}\text { 分化期 } \\
\text { 夢片初 } \\
\text { 生 }\end{array}$ & $\begin{array}{l}\text { 未分化 } \\
\text { 未分化 } \\
\text { 未分化 } \\
\text { 雄菲初 } \\
\text { 生 }\end{array}$ & $\begin{array}{l}\text { 分化 } \\
\text { 雄蓰 } \\
\text { 成 } \\
\text { 花瓣 } \\
\text { 战 }\end{array}$ & 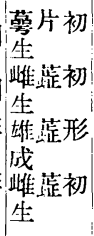 & 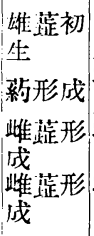 & 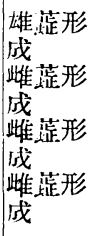 & $\begin{array}{l}\text { 此薄 } \\
\text { 生 } \\
\text { 此踏 } \\
\text { 生 } \\
\text { 花粉 } \\
\text { 成 } \\
\text { 花粉 } \\
\text { 战 }\end{array}$ & $\begin{array}{l}\text { 花粉 } \\
\text { 娍 } \\
\text { 花粉 } \\
\text { 成 } \\
\text { 花粉 } \\
\text { 宬 } \\
\text { 花粉 } \\
\text { 成 }\end{array}$ \\
\hline
\end{tabular}

註：各移植凅に於ける進度の最も進みしを以て示す

第 8 表 花芽發育進度表 (1937.6.28 苗取區)

\begin{tabular}{|c|c|c|c|c|c|c|c|c|c|c|c|c|c|c|c|}
\hline 日 & $\begin{array}{c}\text { 進 } \\
\text { 別 }\end{array}$ & $\begin{array}{l}\text { 供 } \\
\text { 試 } \\
\text { 株 } \\
\text { 數 }\end{array}$ & $\begin{array}{l}\text { 未 } \\
\text { 分 } \\
\text { 化 }\end{array}$ & $\begin{array}{l}\text { 分 } \\
\text { 华 } \\
\text { 初 } \\
\text { 期 }\end{array}$ & 分 & $\begin{array}{l}\text { 䓪 } \\
\text { 片 } \\
\text { 初 } \\
\text { 生 }\end{array}$ & $\begin{array}{l}\text { 䓪 } \\
\text { 形 } \\
\text { 成 }\end{array}$ & $\begin{array}{l}\text { 花 } \\
\text { 被: } \\
\text { 生 }\end{array}$ & $\begin{array}{l}\text { 花 } \\
\text { 哧 } \\
\text { 形 } \\
\text { 戊 }\end{array}$ & 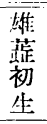 & $\begin{array}{l}\text { 雄 } \\
\text { 䇛 } \\
\text { 形 }\end{array}$ & $\begin{array}{l}\text { 雌 } \\
\text { 初 } \\
\text { 生 }\end{array}$ & $\begin{array}{l}\text { 政 } \\
\text { 篮 } \\
\text { 战 }\end{array}$ & $\begin{array}{l}\text { 新 } \\
\text { 形 } \\
\text { 戊 }\end{array}$ & $\begin{array}{l}\text { 花 } \\
\text { 粉 } \\
\text { 形 } \\
\text { 战 }\end{array}$ \\
\hline$\stackrel{\text { H }}{9.15}$ & 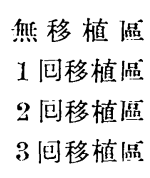 & $\begin{array}{l}5 \\
5 \\
5 \\
4\end{array}$ & $\begin{array}{l}5 \\
5 \\
5 \\
4\end{array}$ & & & & & & & & & & & & \\
\hline 20 & $\begin{array}{l}\text { 無移植澏 } \\
1 \text { 问移植湂 } \\
2 \text { 包移植活 } \\
3 \text { 泡移植澏 }\end{array}$ & $\begin{array}{l}5 \\
5 \\
5 \\
5\end{array}$ & $\begin{array}{l}5 \\
5 \\
5 \\
4\end{array}$ & 1 & & & & & & & & & & & \\
\hline 25 & 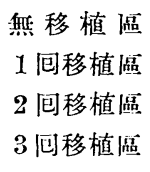 & $\begin{array}{l}5 \\
5 \\
5 \\
5\end{array}$ & $\begin{array}{l}5 \\
5 \\
2 \\
2\end{array}$ & 1 & $\begin{array}{l}2 \\
2\end{array}$ & 1 & & & & & & & & & \\
\hline 30 & 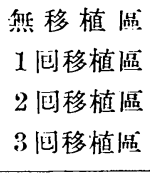 & $\begin{array}{l}5 \\
5 \\
5 \\
4\end{array}$ & $\begin{array}{l}5 \\
5 \\
5 \\
1\end{array}$ & 1 & & & 1 & & & 1 & & & & & \\
\hline 10. 5 & 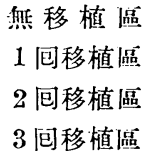 & $\begin{array}{l}5 \\
5 \\
5 \\
4\end{array}$ & $\begin{array}{l}3 \\
1 \\
1 \\
1\end{array}$ & 1 & $\begin{array}{l}2 \\
3 \\
3 \\
1\end{array}$ & & & & 1 & & 1 & & & & \\
\hline
\end{tabular}


江曰, 松尾, 中柴, 育苗中の移植が蓝の花芽分化並化芽の發育に及ぼす影響に就て 99

\begin{tabular}{|c|c|c|c|c|c|c|c|c|c|c|c|c|c|c|}
\hline 10.11 & 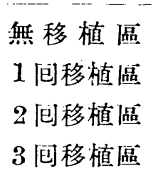 & $\begin{array}{l}5 \\
5 \\
5 \\
5\end{array}$ & 2 & 1 & $\begin{array}{l}2 \\
1 \\
1\end{array}$ & $\begin{array}{l}1 \\
2 \\
2 \\
1\end{array}$ & $\begin{array}{l}1 \\
2 \\
1\end{array}$ & & & $\begin{array}{l}1 \\
1\end{array}$ & $\begin{array}{l}1 \\
1\end{array}$ & & & \\
\hline 15 & 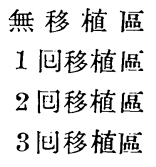 & $\begin{array}{l}5 \\
5 \\
5 \\
4\end{array}$ & 1 & & 1 & $\begin{array}{l}1 \\
1\end{array}$ & 1 & $\begin{array}{l}1 \\
1\end{array}$ & $\begin{array}{l}2 \\
1\end{array}$ & 1 & $\begin{array}{l}1 \\
2 \\
2\end{array}$ & $\begin{array}{l}1 \\
1\end{array}$ & 1 & \\
\hline 20 & 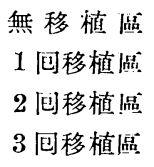 & $\begin{array}{l}5 \\
5 \\
4 \\
5\end{array}$ & 1 & & & 1. & & & $\begin{array}{l}1 \\
2 \\
1\end{array}$ & $\begin{array}{l}3 \\
1 \\
1 \\
1\end{array}$ & 1 & $\begin{array}{l}1 \\
3 \\
1\end{array}$ & & \\
\hline 30 & $\begin{array}{l}\text { 無移植湂 } \\
1 \text { 包移植盛 } \\
2 \text { 问移植區 } \\
3 \text { 可移植區 }\end{array}$ & $\begin{array}{l}4 \\
5 \\
5 \\
4\end{array}$ & & & & & & & 1 & $\begin{array}{l}1 \\
2 \\
1\end{array}$ & $\begin{array}{l}3 \\
2 \\
1\end{array}$ & & $\begin{array}{l}1 \\
1\end{array}$ & $\begin{array}{l}3 \\
2\end{array}$ \\
\hline 11.10 & 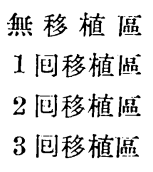 & $\begin{array}{l}5 \\
5 \\
5 \\
4\end{array}$ & & & & & & & & 2 & 1 & & $\begin{array}{l}1 \\
2\end{array}$ & $\begin{array}{l}1 \\
3 \\
5 \\
4\end{array}$ \\
\hline
\end{tabular}

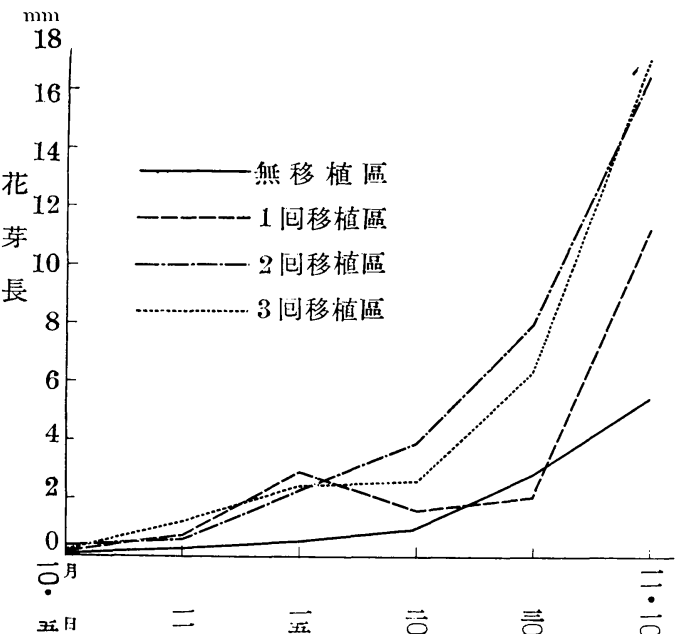
材料探集月日

第6 圖 花芽長比較(1937.6.28苗取區)

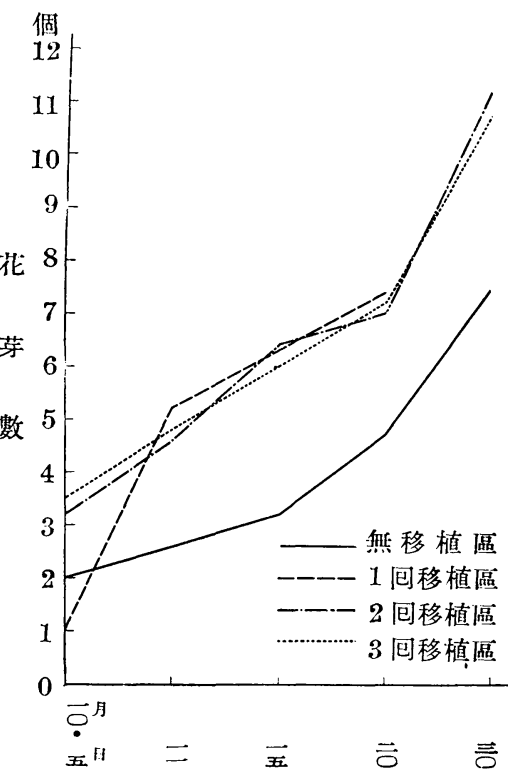

材料探集月日

第 7 圖 花芽數比較 1937.6.28苗取區 


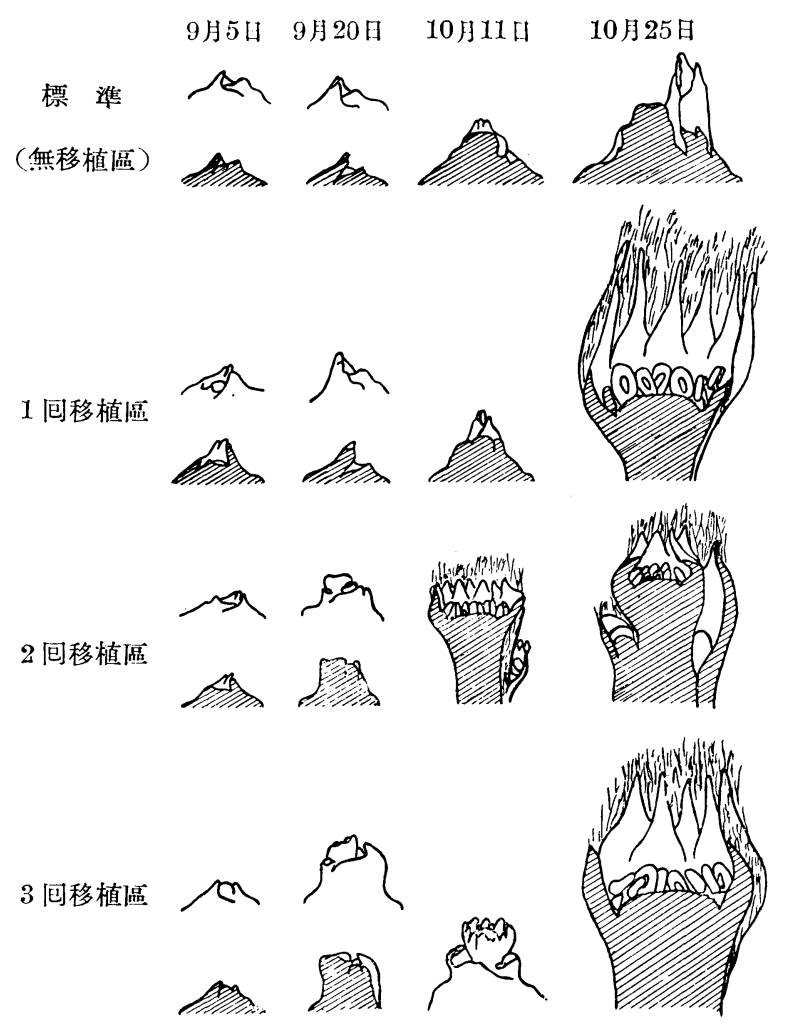

第 8 圆 移植问數が莪の花芽分化・發育に及ぼす 影響（1937.6.28 苗取區）（福犲種）

以上に依れば 6 月 16 日苗に就て得た結果と略从同樣に無移植區の花芽の發 育最も後れ，移植包數を䅛す每沉花芽の發育が促進されて居る。

（d）花芽分化當時に於ける移植(定植)が花芽の發奇に及质す影響

( 6 月 28 日苗) (福呵)

此の年に於ける標準 (無移植區) の花芽分化期は 9 月 25 日と 10 月 5 日の間 に在つた。分化當時に於ける移植（定植一斷根）が其後の花芽の發育に如何な る影響を及代すかを知らんが䈆め 10 月 3 日に苗の一部を本围に定植して 10 月 11 日，10月 20 日，10月 30 日，11月10日に萌を取つて花芽の發育を比較し て見た，其の結果は第 9 表，第 9 圖，第 10 圖，第 11 圖，第 12 圖に示す通り である。 
江口,松尾, 中柴, 育苗中心移植が莄の花芽分化並花芽の發育に及ぼす影绵に就て 101

第 9 表花芽發育比較（1937）

\begin{tabular}{|c|c|c|c|c|c|c|c|c|c|c|c|c|c|c|c|}
\hline 日 & 進 & $\begin{array}{l}\text { 供 } \\
\text { 試 } \\
\text { 株 } \\
\text { 數 }\end{array}$ & $\begin{array}{l}\text { 未 } \\
\text { 分 } \\
\text { 化 }\end{array}$ & $\begin{array}{l}\text { 分 } \\
\text { 化 } \\
\text { 初 } \\
\text { 期 }\end{array}$ & $\begin{array}{l}\text { 分 } \\
\text { 化 } \\
\text { 期 }\end{array}$ & $\begin{array}{l}\text { 䓪 } \\
\text { 初 } \\
\text { 生 } \\
\end{array}$ & $\begin{array}{l}\text { 苪 } \\
\text { 年 } \\
\text { 形 } \\
\text { 成 } \\
\end{array}$ & 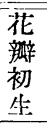 & $\begin{array}{l}\text { 花 } \\
\text { 辝 } \\
\text { 形 } \\
\text { 战 }\end{array}$ & 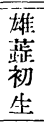 & $\begin{array}{l}\text { 雄 } \\
\text { 茈 } \\
\text { 形 } \\
\text { 战 }\end{array}$ & 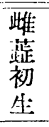 & 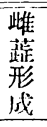 & $\begin{array}{l}\text { 苇 } \\
\text { 形 } \\
\text { 成 }\end{array}$ & $\begin{array}{l}\text { 花 } \\
\text { 粉 } \\
\text { 形 } \\
\text { 戊 }\end{array}$ \\
\hline $10^{\text {月 }} 11$ & 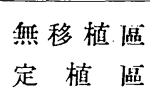 & $\begin{array}{l}5 \\
4\end{array}$ & 2 & 1 & $\begin{array}{l}2 \\
1\end{array}$ & $\begin{array}{l}1 \\
2\end{array}$ & & & & & & & & & \\
\hline 20 & $\begin{array}{l}\text { 無移植澏 } \\
\text { 定 植 區 }\end{array}$ & $\begin{array}{l}5 \\
5\end{array}$ & 1 & & & 2 & 1 & & & $\begin{array}{l}1 \\
2\end{array}$ & 3 & & & & \\
\hline 30 & $\begin{array}{l}\text { 無移植區 } \\
\text { 定植 澏 }\end{array}$ & $\begin{array}{l}4 \\
5\end{array}$ & & & & & & & & 1 & $\begin{array}{l}1 \\
4\end{array}$ & 3 & & & \\
\hline $11 \quad 10$ & $\begin{array}{l}\text { 無移植湂 } \\
\text { 定 植 品 }\end{array}$ & $\begin{array}{l}5 \\
5\end{array}$ & & & & & & & & & $\begin{array}{l}2 \\
2\end{array}$ & $\begin{array}{l}1 \\
3\end{array}$ & & 1 & 1 \\
\hline
\end{tabular}

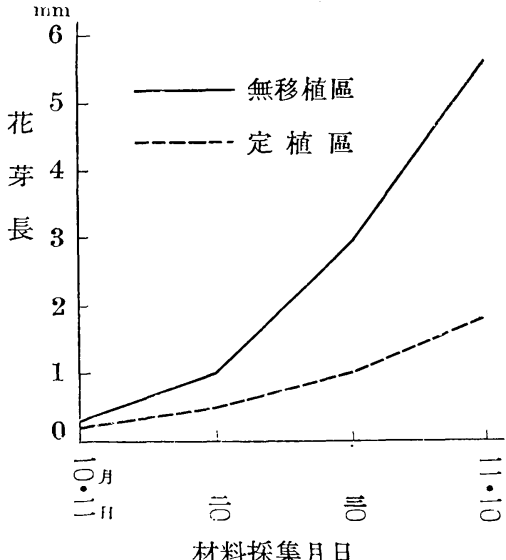

材料探集月日

第 9 圖 花芽長比較 (1937)

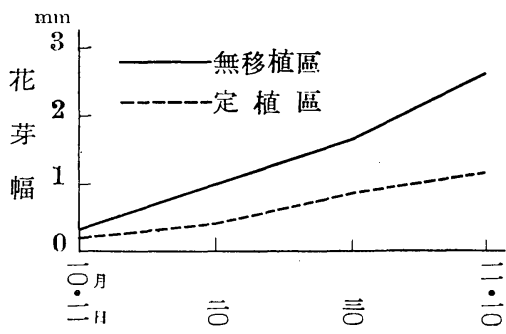

材料琛集月口

第10圖 花芽幅比較（1937）

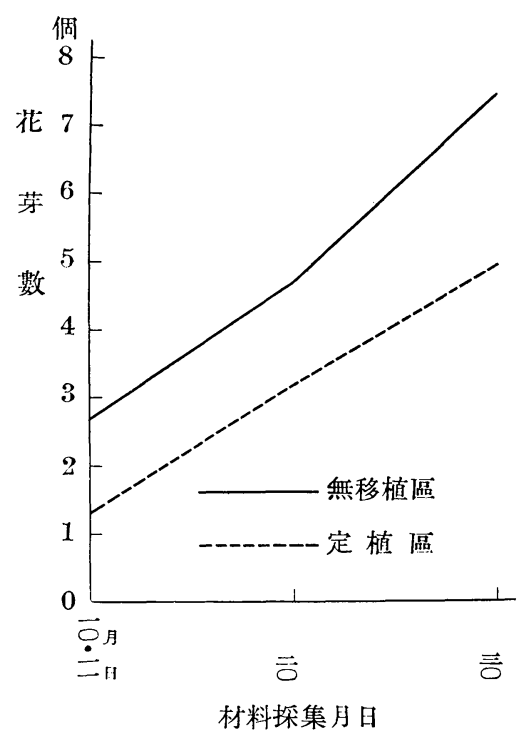

第11圖 花芽數比較 (1937) 


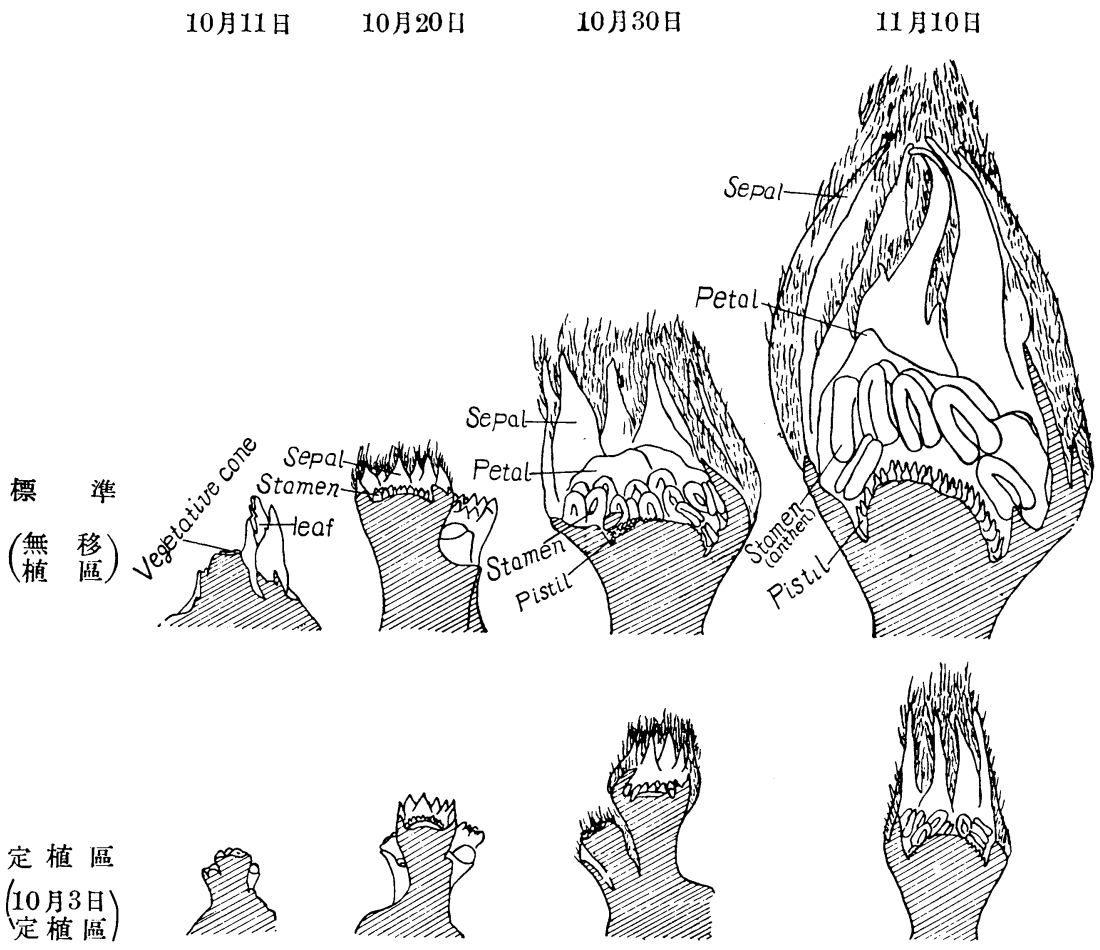

第 12 圖 定植時に於ける移植が苗の花芽發育に及ぼす影響 (1937)

註 無移植凅は一度も移植を行はず其㯰荫祙に殘上しもの 定植澡は育苗中移植を行はず 10 月 3 日本间に定植せし.もの

以上結果に依れば花芽分化當時に於ける移植 (定植) 區は無移植區に比較し て, 花器の形成, 花芽の發育共に著しく後れ花芽分化前に受けた移植の影響と 全く反對結果である。

(e) 要約

以上 2 ヶ年，4包に亘つて行つた實驗結果から見れば，花牙分花前に行つた 移植操作は花牙分化期を促進する傾向見へ，花芽分化當時に行つを移植(定植) は花牙の發育を著しく後らし，花芽の分化數をも減少して居る。

3. 荘の發育に及社す影響

育苗中の移植が苗の發蒿に及在す影響を，草丈，葉の枚數 (外葉), 重量 (地 上部）に就んて比較すれば第 $13,14,15,16,17,18,19$ 圖に示す通りである。 


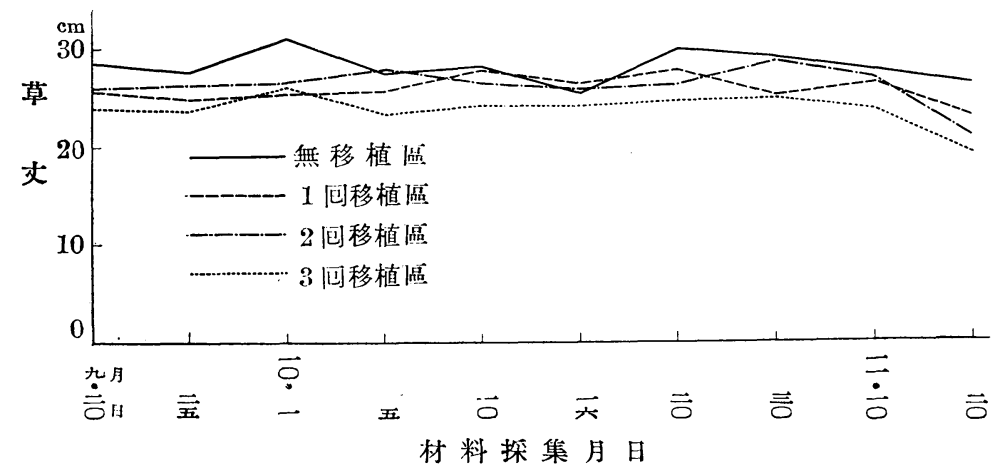

第 13 圖草艾比較（1936）（大島種）

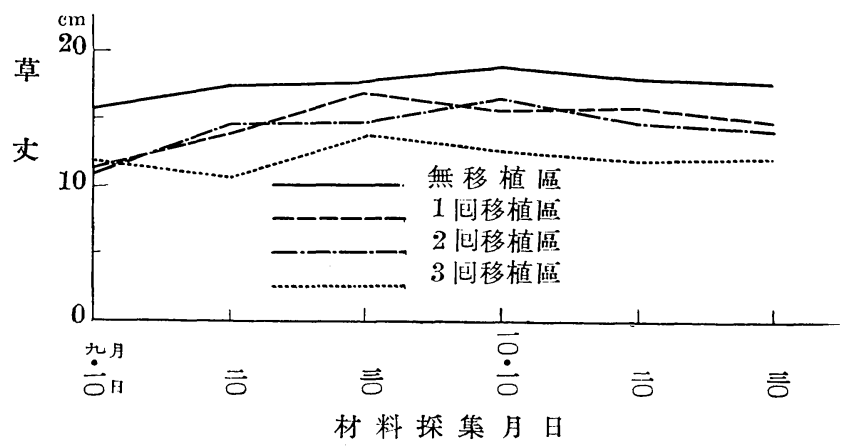

第 14 圖草文比較 (1937.3.16苗取區)

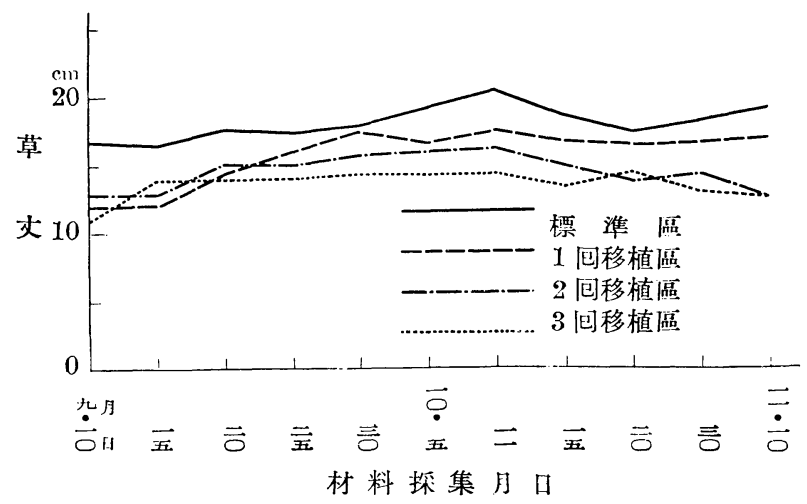

第 15 圖 草文比較 (1937.6.28苗取區) 


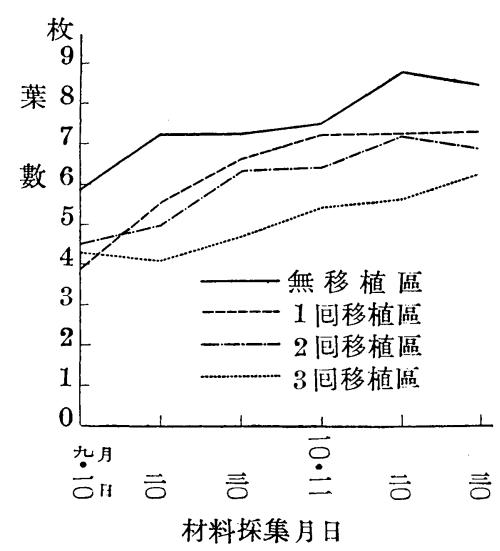

第16圖 葉數比較 1937.6.16苗取區 (註：葉數は外葉數比較)

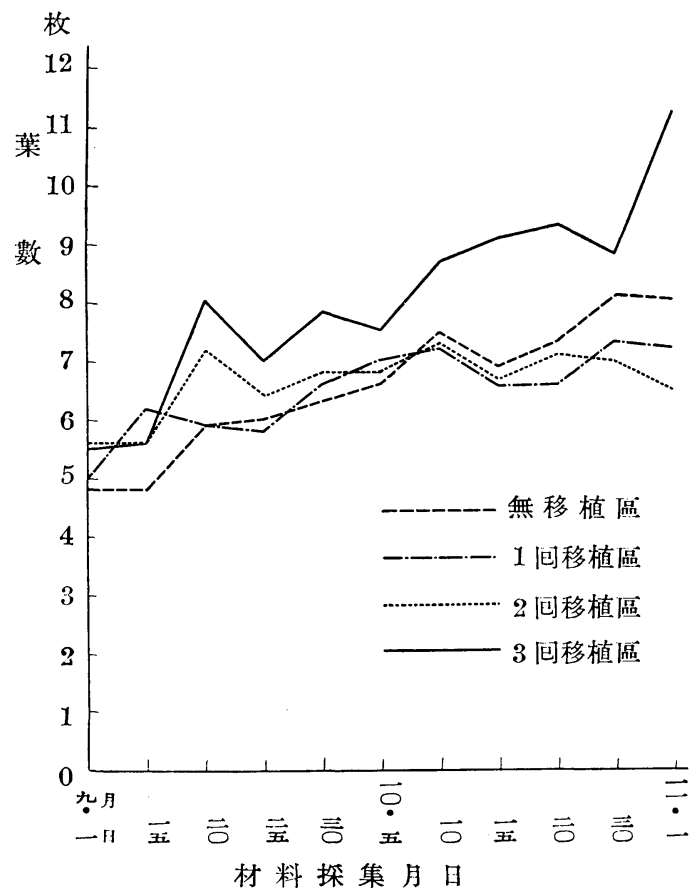

第 17 圖 葉 數 比 較 1937.6.26苗取區

（註：葉數は外葉數比較）

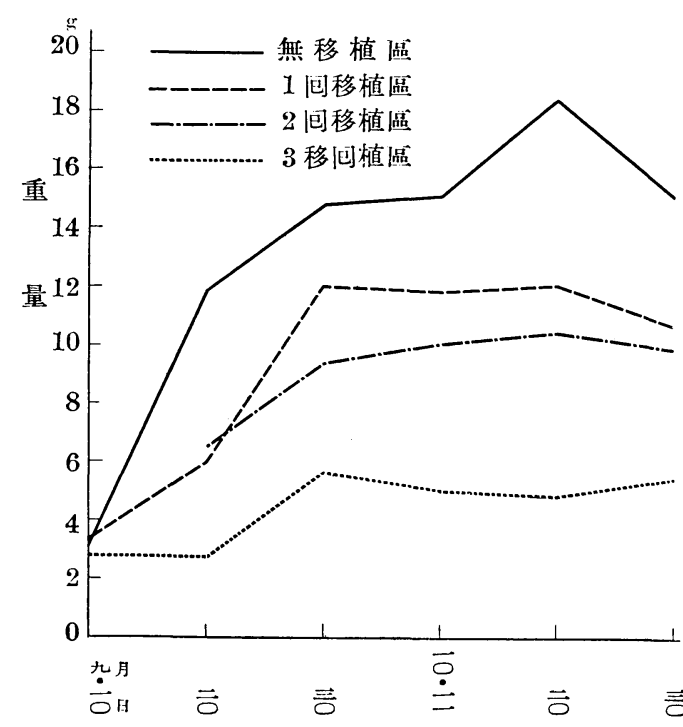

材料探集月日

第 18 圖 重量比較 1937.6.16苗取區 （註：重量は地上部重量比較）

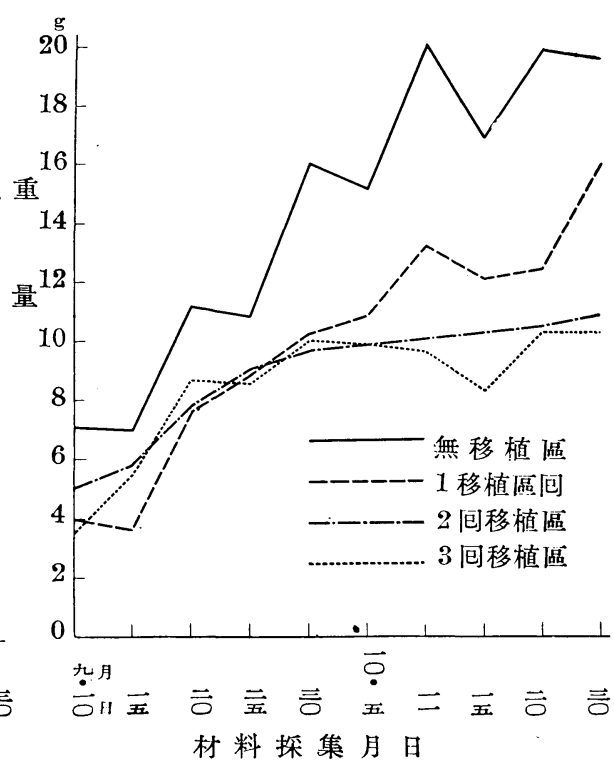

第 19 圖 重量比較 1937.6 28苗取區 （註：重量は地上部重量比較） 
江几, 松尾, 中柴, 育苗中の移植が英の花芽分化並花芽の發育に及ぼす影锌に就て 105

以上に依れば草丈，葉枚數，重量共に無移植區の發育最も秀れ，何れに於て 移植包數を增す每に發育は後れて居る。

\section{IV 考察}

以上結果は次の 3 階程に分けて考案され得るものと思ふ。

(A) 育苗中の移植が盟の發育に及情す影響

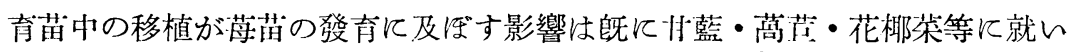
て行はれた LoOMIS (1925), WeAVER(1927)(1929), Thompson(1923), CraNEFieLD (1899), LLOYD(1910)，淺見敎授 $(1934)$ ，熊㵏氏 (1936) 等の實驗及筆者等が暴に 行つた茄子・トマトの場合と略ら同樣に移植操作は萌の發育を阻碍し negative の影響学及卧して居る。

（B）茼苗中の移植が花芽分化期に及将す影響

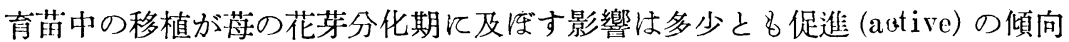
が見へて居る。此事は MAGNeSs (1916), HARver (1921), MURneEK (1928), G (7) て摘葉は果樹類の花芽分化期に惡影響を及庄すと述べ，筆者等が暴に茄子・卜 マトに就て育苗中の移植操作は花芽分化期を後らす結果を得て居るのと反對で ある。茄子・トマトに就いては, 着花節位が略々一定し, 花芽分化期の早晚は 苗の發育之密接不可分の關係に在る事を明らかにして通いた。薄の花芽分化期 が育苗中の移植操作に依つて促進される原因に就いては今後尚性幾多の實驗を 續けねばなら好事と思ふが，菌は先づ第一に茄子・トマトと異り某の枚數，苗 の大小とは殆んど無關係に花芽を形成し得るものである。つまり菌は或程度の 苗であれば環境如何に依つて容易に花牙を形成し得る性質を持つものである。 斷根が花芽形成を促進する原因に就て LOEW (1905) 氏は次の樣に述べて居る。 斷根に依つて根部が少くなり，引いては根部の呼吸作用に依つて消費される糖 分が少くなり，地上部の糖分が火れだけ多くなつて糖分濃度が高まるからであ ると爲し，根部が版盛な生長をして居る間は葉で出來を糖分の多量は根部に運 ばれ，根部の生長が弱まるか，又は葉面積が多くなつて立分多量の糖分を生成 する事が出來るやうになつて始めて地上部の糖分濃度が花芽形成を引起すだけ の高さに達するとして居る。篗者等は別に薄の根の調查を進めて居るが，根の 活動と花芽分化期との間には何等かの關係があるやうに思はれて居る。

(C) 花芽分化當時に於ける移植(定植)が花芽の發育に及优す影響 
花牙分化當時に行はれる移植(定植)操作は花芽の發育を阻碍し花芽分化數を も減少し，花芽分化前に行はれる移植の影響とは全く反對であつて，營羪器官 の發育上に受ける影響と略々同樣である。

今，呬栽培上の實情より見れば，一般露地菖の場合には，6月の梅雨中に苗 (ランナー)を取つて苗仕立てを行ひ 10 月又は 11 月に灯地或は水田に定植を 行ひ，育苗中には一般に移植を行つて居ない。斯樣にして栽培した一年苗は， 其倨固場に殘された 2 年乃至 3 年萠に比較して收量劣り，中には收量の牛減す 場合も珍らしくない，是れには 1 年生萠の根が淺く，冬期乾燥期に依つて受け るる被害も考へねばならないが，定植時に花芽の受ける影響も當然考虑に入れ ねばならなん。斯樣な見地から苗の定植に當つては，成る可く多數の根を付け て，苗の傷まないやう從前以上に叮寧な取扱を爲す可きだと思ふ。

今日，荫の促成栽培の場合には，一般に育苗中に移植を行ひ，靜岡縣下蒲原 町，久能地方では 2 包〜 3 包，神奈川縣寒川地方では 1 包〜 3 包，千葉縣市川 附近では無移植又は 1 四の移植が行はれて居る，夫れ等當業者の言を綜合する と，無移植苗を使用した場合には開花期稍々後れ，1 包移植苗は中に開花の促 進されるものと，後れるものがあつて開花が不揃ひとなり，2包〜 3 包移植苗 は開花が促進されて開花期も亦揃ふと云ふ。先般折良く市川附近の促成薄の開 花中に行つて直接調查の機會を得たが火れ等の幑候は良く現はれて居た。（第

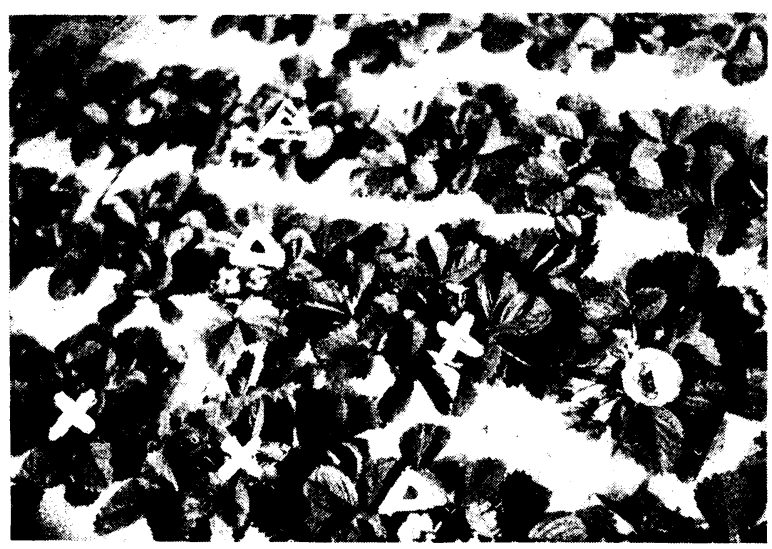

第 20 圖 無移植苗の開花狀況 (13.12.3)

育渵中無移植苗は開花期稍々後れるがよく舫二て開花する。 定植期は 10 月になってからょり9月 20 口〜23日を適期とす る。此時期は花芽分化期の約10日前に當つて居る。
20,21 與參监)。以上 結果を笰者等の得を實 驗結果と尛合すれれば， 無移植苗が移植畒に比 較して開花期の後れる 事は篗者等の得た，移 植之花芽分化期の早晚 との關係とよく一致す る。佾痤 1 包移植苗の 開花期が不揃ひを來た す原因に就いては今後 實驗を進めねばならな いが, 此際考入得られ 


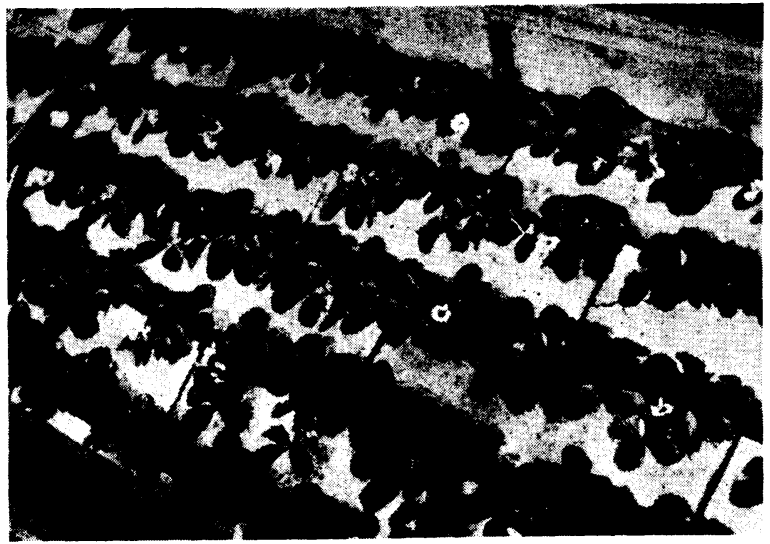

第 21 圖 1 包移植苗の開花狀況 (13.12.3)

育苗中 1 包移植苗出開花の特沉早、のや後れるのがあつてマ チマチである。最も早く開花した株仕無移植苗より約 20 日早 く, 後れたものは約 20 日程後れる, 結局同じ框の中で一番早 いのと遲いのとの間には約 40 日の開をがある。

註 : $\bigcirc \cdots \cdots$ 結苗期飞入った株

$\triangle \cdots \cdot$ 開花又は結實中の株

$\times \cdots$ 未開花株(約 40 日後れて開花する)
る事は，1.包移植に依 つて花芽の分化期は多 少促進されて居ても， 定植の際の斷根に依つ $\tau ， 今$ 度は逆に花芽の 發育を阻碍する結果と なり，此の 2 つの相反 する動きがヂクザクに 影響して，或株は開花 が促進され，或株は開 花期の後れるやうな結 果を來したのではある まいかと考へられる。 向瓜2 包移植苗は移植 飞依つて分化期が促進

され，其上淀植の際の打擊が最も少く開花期促進され，而もよく開花期揄つ たものと見る事が出來る。育苗中多少の勞力を要する事ではあるが，開花の量 よりは，開花期の早をを望む促成の場合には，育苗中にさ同程度の移植を行る 事は合理的な事だと思はれる。因みに籍者は本實驗で得た，花芽分化當時に行 ふ移植（斷根）が花芽の發育に惡影響を及度す結果に鑑み，他の一般の作物に 就いても本實驗を進めて見度い考へである。

\section{$\mathbf{v}$ 摘 要及結 論}

1. 育苗中並に花芽分化當時に行ふ移植( 又は定植)が薄の花芽分化並花芽の 發育に如何なる影響を及庄すかに就て實驗で行つた。

2. 育苗中に行ふ移植は苗苗の發育を僬延せしめる。

3. 育苗中の移植は茵の花牙分化期を促進し，花牙の發育を促進する。

4. 花芽分化當時に行ふ移植( 又は定植) は花牙の發育を阻碍し花牙分化數を 減少する。

5. 露地苺の定植に當つては，當時 (10月〜11月), 丁度䓅の第 1 花房〜第 2 花房分化時期飞當るを以て，苗の取扱ひはより叮嚊に行ふ可きだ思ふ。

6. 促成苺の育甶に當り，育甶中 2 包程度の移植を行ふ事は，花牙分化期を 
促進し, 定植時(10月上旬, 花芽分化時期)に於ける打擊を少くする意味から穻 當な事だと思ふ。

\section{VI 用文 献}

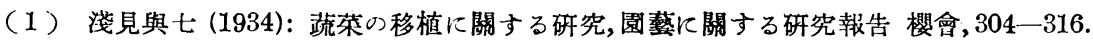

(2) Cranefield, F. (1899): The effect of transplanting on time of maturity. Ann. Rept. Wis. (Quoted by Thompson)

（3）江口麻雄 (1934)：低溫及土壤の乾濕之英の花芽分化期之の關保に就て (豫報) 園藝 學會䊒誌，第 5 突，第 2 號，233-250.

（4）江口庸雄 (1935)：菌の苗取り時期之花芽分化期並花芽の發育との關係に就て，園藝 學會嚾誌, 第 6 釡, 第 1 號, 84--104.

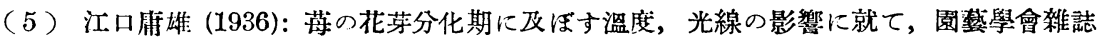
第 7 夋, 第 1 號, $19-26$.

（6）江口痛雄 (1938)：育苗中の移植が菭子・蕃茄の花芽分化，花芽の發育並に附花結惯 に及ほす影響に就て，園藝學會雜誌、第 9 父, 第 3 號, 259-281.

( 7 ) Gardner, V. (1933): Studies in the nutrition of the strawberry. Missouri Agr. Exp. Sta. Bull. 57.

(8) Harvey, E. and Murneek, E. (1921): The relation of carbohydrates and nitrogen to the behavior of apple spurs. Ore. Agr. Exp. Sta. Bull. 176.

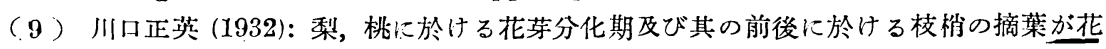

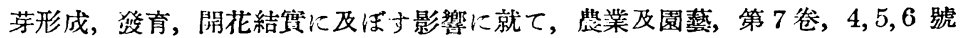

（10）熊澤三郎，南川朌次 (1936)：甘嵓類の移植が活着並に生育に及ほす影響，園藝の研 究, 第 32 號、74-84.

(11) Lloyd, J. and Brooks, I. (1910): Growing tomatoes for early market. Ill. Bull. 144.

(12) Loww, O. (1905): Zur Theorie der bliitenbildende Stoffe. Flor 94: 124128. 淺見與七，果樹栽培沉諭，33頁引用.

(13) LoEw, O. (1905): Stickstoffentziehung und Blütenbildung. Flora. 95: 324326. 淺見與七, 果樹栽培沉論, 33面引用.

(14) Loomis, W. (1925): Studies in the transplanting of vegetable plants. Cornell Univ. Agr. Exp. Sta. Mem. 87.

(15) Magness, G. (1916): The influence of summer pruning on bud development in the apple. Oreg. Agr. Exp. Sta. Bull. 139.

（16）三輪忠珍 (1935)：環狀䟝皮，摘心及除葉が桃の花芽形成に及ぼす影響，園藝學會猚 誌, 第 6 忩, 第 2 號.

（17）三輪忠珍 (1937)：環狀㹺皮，摘心及除葉が桃の花芽形成に及ぽす影響，園藝學研究 集錄, 第 2 輯.

(18) Murneek, A. E. (1928): Effect of pruning on the carbohydrate-nitrogen ratio in the tomato. Proc. Amer. Soc. Hort. Sci. Vol. 24.

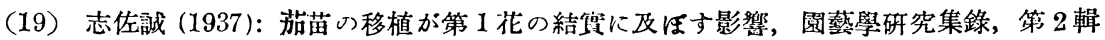

(20) Thompson, M. (1923): Vegetable Crops.

(21) Weaver, E. and E. Bruner (1927): Root development of vegetable crops.

(22) Wrayer, E. and E. Clement (1929): Plant ecology. 